\title{
Liter per Day per Meter Squared
}

National Cancer Institute

\section{Source}

National Cancer Institute. Liter per Day per Meter Squared. NCI Thesaurus. Code C120738.

A unit of concentration equal to liter per day divided by meter squared. 